Bartın Üniversitesi İktisadi ve İdari Bilimler Fakültesi Dergisi, 2020, Cilt 11, Sayı 22

Bartın University Journal of Faculty of Economics and Administrative Sciences, 2020, Volume 11, Issue 22

ISSN: 1309-954X / E-ISSN: 2148-2497

http://iibfdergi.bartin.edu.tr/

http://dergipark.gov.tr/bartiniibf

Araştırma Makalesi, Gönderim Tarihi: 26.06.2020; Kabul Tarihi: 08.11.2020

\title{
Finansal Yönetim Eğitimi Alan Öğrencilerin Algı ve Finansal Okuryazarlık Düzeyleri Üzerine Bir Araştırma
}

\author{
Öğr. Gör. Mehmet TURSUN \\ Adıyaman Üniversitesi, Kahta Meslek Yüksek Okulu \\ mtursun@adiyaman.edu.tr Orcid ID: 0000-0001-9731-2198 \\ Öğr. Gör. Abdulrezzak İKVAN \\ Adıyaman Üniversitesi, Kahta Meslek Yüksek Okulu \\ aikvan@adiyaman.edu.tr Orcid ID: 0000-0002-9834-237X \\ Dr. Öğr. Üyesi İsmail UKAV \\ Adıyaman Üniversitesi, Kahta Meslek Yüksek Okulu \\ iukav@adiyaman.edu.tr Orcid ID: 0000-0003-2922-6946
}

\section{$\ddot{O} \mathbf{z}$}

Bireylerin finansal refahını arttırmada doğru finansal araçların seçilmesi onların finansal bilgi, beceri ve yeterlilik düzeyine ulaşması ile mümkündür. $\mathrm{Bu}$ kapsamda finans okuryazarı olmanın büyük önemi bulunmaktadır. Bu çalışmada, Adıyaman Üniversitesi Kâhta MYO Finans, Bankacılık ve Sigortacılık ile Muhasebe ve Vergi bölümlerinde öğrenim gören öğrencilerin Finansal Yönetim dersi kapsamında derse ilişkin algılarının ve finansal okuryazarlık düzeylerinin belirlenmesi amaçlanmış ve kapsamdaki 88 öğrencinin verileri anket kullanılarak elde edilmiştir. Araştırma sonuçlarına göre öğrencilerin finansal yönetim dersine yönelik algılarının güçlü olduğu, finansal okuryazarlık düzeylerinin cinsiyet ve bölümlere göre farklılık göstermediği ancak öğrencilerin başarı notu ortalamalarına göre farklılık gösterdiği tespit edilmiştir. Finansal okuryazarlık düzeyinin artması için üniversitelerde, sektörün nitelikli eleman gereksinimini karşılayacak şekilde finans eğitim programlarının geliştirilmesinin gerekliliği göz önünde bulundurulmalıdır.

Anahtar Kelimeler: Finansal Okuryazarlık Düzeyi, Finansal Eğitim, Tasarruf, Yatırım JEL Sınıflandırması: D14, E21, G11 


\title{
Research on The Perceptions and Financial Literacy Levels of Students with Financial Management Education
}

\begin{abstract}
Choosing the right financial instruments to increase the financial well-being of individuals is possible for them by reaching the level of financial knowledge, skill and competence. In this context, being financially literate is of great importance. In this study, it was aimed to determine the perceptions of Financial Management course students about the course and their financial literacy level. For this purpose, data were collected with using questionnaire from 88 students studying in Finance, Banking and Insurance and Accounting and Tax departments of Adiyaman University Kâhta Vocational School. According to the results of the research, it was determined that students' perceptions about the financial management course were strong, financial literacy levels did not differ according to gender and departments, but differed according to the grades of students'. In order to increase the level of financial literacy, the necessity of developing financial education programs in universities to meet the qualified personnel requirement of the sector should be taken into consideration.
\end{abstract}

Keywords: Financial Literacy Level, Financial Education, Savings, Investment

JEL Classification: D14, E21, G11

\section{Giriş}

Günümüzde ekonomide baş döndürücü gelişmeler yaşanmaktadır. Bu gelişmeleri anlayabilmek ve buna uygun davranış yöntemleri oluşturmak son derece önemli hale gelmiştir. Bunun bir yansıması olarak da finansal piyasalar oldukça kapsamlı boyutlara ulaşmıştır. Bu piyasalarda her geçen gün yeni gelişmeler ortaya çıkmaktadır. Finansal yap1 içerisinde yaşanan bu değişikliler ve gelişmeler sistemi karmaşık hale getirebilmektedir. $\mathrm{Bu}$ karmaşa, sistem içerisinde yer alan bireylerin karar alma süreçlerini olumsuz yönde etkiyebilmektedir. $\mathrm{Bu}$ nedenle alınacak finansal kararlar bireylerin ekonomik yaşamları için de son derece önemli olacaktır. Finansal karar alma konumunda olanların bu süreçte yeterli ve uygun bir finansal bilgi düzeyine sahip olmaları önem taşımaktadır.

Dolayısıyla burada finansal bilgi birikimi ön plana çıkmaktadır. Kişilerin finansal bilgi düzeyleri finansal okuryazarlık seviyelerini belirlemede oldukça önemli bir faktördür (Tüfekçi vd., 2017: 58-72). Bununla birlikte finansal piyasaların işleyişi ile ilgili temel düzeyde bilgi sahibi olmanın yanında bu bilgilerin tutum ve davranışlara yansıtılması gerekmektedir. Finansal okuryazarlık kişinin; bilgi, beceri, tutum ve davranışları ile parasını iyi yönetebilme, finansal sistem ve araçlarının işleyişi hakkında bilgi sahibi olma, finansal planlar yapabilme, etkili bir iletişim kurabilme gibi özelliklere sahip olması beklenebilir (Gökmen, 2012: 205). 
Finans ve türevleri, bireylerin tutum ve davranışlarıyla şekillenmesinden dolayı sosyal bir bilim olmasının yanı sıra derin analizlerin gerekliliği nedeniyle genelde yalnızca uzmanların bir uğraşı alanı olarak algılanmaktadır. Aslında, finansal konular tüm kesimlerin ilgi alanına girmektedir. Ancak finansal sistemin en büyük paydaşları olan tüketici grubu, sistemin karmaşık yapısından dolayı uzmanların kuklaları haline gelmiştir. Finans sisteminde bu denli önemli bir yere sahip olan tüketici grubu bu sistemin dışında kalarak uzmanlara teslim olmuştur. Bireyler yaşamlarının her anında farklı boyutlarda finansal kararlar almakta ve bu kararlar ilgili bireylerin yaşam şekillerini önemli ölçüde etkilemektedir (Biçer ve Altan, 2016: 1510).

Finansal okuryazarlıkla ilgili olarak yapılan çalışmalarda bireylerin karmaşık yapıları nedeniyle günümüz finansal ürün ve araçlarını kavrama ve değerlendirmede güçlük çektikleri anlaşılmaktadır. Yeterli bilgi birikimine sahip olmadan bilinçsizce alınan kararlar, tarafları ve finansal sistemi olumsuz bir şekilde etkileyebilmektedir. Bu olumsuzlukları engellemek ve bireylerin finansal gelişmelerden etkin bir şekilde faydalanmalarını sağlamak için finansal okuryazarlık düzeyinin artırılması önemlidir. (Elmas ve Y1lmaz, 2016: 138). Dolayısıyla, Finansal okuryazarlık seviyesini yükseltmenin en temel koşullarından birisi bireylerin finans konularında alacakları eğitimin nicelik ve nitelik olarak geliştirilmesidir.

Türkiye'de lisans düzeyinde finansal okuryazarlığın belirlenmesine yönelik oldukça fazla sayıda çalışma yapılmasına rağmen meslek yüksekokullarında öğrenim gören öğrencilere yönelik ilgili konudaki çalışmaların sayısı oldukça azdır. Bu nedenle meslek yüksekokullarının bir örneği olarak Adıyaman Üniversitesi Kâhta Meslek Yüksekokulu öğrencilerinin finansal okuryazarlık düzeyleri incelenmiştir. Bu çalışmada, Finans, Bankacılık ve Sigortacılık Bölümü ile Muhasebe ve Vergi Bölümü öğrencilerinin finansal okuryazarlık bilgi düzeyleri ve bu bilgi düzeylerinin çeşitli faktörlere göre farklılık gösterip göstermediğinin belirlenmesi amaçlanmıştır. Bu amaçla öncelikle finansal okuryazarlık ile ilgili kavramsal çerçeve ortaya konulmuş, konu ile ilgili literatür çalışmaları özetlenmiş ve öğrencilerin finansal okuryazarlık bilgi düzeyleri belirlenmiştir.

\section{Finansal Okuryazarlık}

Günümüz ekonomik koşulları, sorumluluk üstlenmiş her bireyin yaşamını ve sorumluluğundaki yaşamları idame ettirebilmeleri için belli düzeyde ekonomi ve finans bilgisine sahip olmalarını gerekli kılmaktadır. Bu durum, kişileri ekonomi ve finans alanlarına ait temel düzey bilgilere sahip olmalarına ve ekonomik hayatta bu bilgileri kullanmaya sevk etmektedir. Konuyla ilgili akademik çalışmalarda finansal okuryazarlık konusu etraflıca araştırılmış ve farklı neticelere ulaşılmıştır. Yapılan çalışmalarda genel olarak finansal okuryazarlığın düşük seviyelerde olduğu belirlenmiş; tasarrufların artması, yatırımların etkinliği, ekonomilerin güçlülüğü gibi pozitif gelişmeler bireylerin finansal okuryazarlık düzeylerinin yükseltilmesiyle mümkün olacağı vurgulanmıştır (Yörük ve Yardımcıoğlu, 2016; Eskici, 2014; Payziner, 2017). 
Ülkelerin gelişmişlik düzeylerine bağlı olarak piyasaların etkinliği farklı düzeylerde olmaktadır. Türkiye gelişmekte olan bir ülke olduğundan finansal piyasası da gelişmekte olan piyasa özelliği taşımaktadır. $\mathrm{Bu}$ kapsamda bireylerin finansal okuryazarlık düzeylerinin yükseltilmesiyle elde edilecek avantajlar bireyler bazında kalmayıp, finansal kaynakların piyasaya akışı ve verimli yatırımlara dönüşmesi sonucunda toplumun refahına katkı sağlayabilecektir (Özçam, 2006).

Bireylerdeki finansal okuryazarlık seviyesinin yüksekliği yatırım ortamında bilgili yatırımcıların varlığını sağlayacak dolayısıyla piyasanın etkinliğine de katkı sunacaktır. Etkin piyasalarda, spekülatörler anormal getiri elde edememekte, yatırımcı girişleri hızlanmakta ve daha gerçekçi bir fiyatlama oluşmaktadır. Aynı zamanda etkin piyasalarda, yatırımcı rekabeti artmakta ve kazanç dağılımı daha adil bir düzende oluşmaktadır.

\subsection{Finansal Okuryazarlık Kavramının Tanımlanması}

Finansal okuryazarlık ile ilgili yapılan tanımlamalar, çalışmaların bakış açılarına göre farklılık gösterebilmektedir. Finansal okuryazarlıkla ilgili yapılan bazı tanımlamalar aşağıda verilmiştir. Buna göre:

Finansal okuryazarlık, işletmelerin finansal durum ve performans tabloları başta olmak üzere finansal bilgilerini okuma ve kavrama kabiliyeti şeklinde ifade edilebilir. Bu tanımlamaya yakın bir tanımlama da Fox vd., (2005: 196) tarafından ifade edilmiş ve finansal okuryazarlık, bireylerin finansal bilgi ve konulardaki anlayış düzeyi olarak tanımlanmıştır. Bu tanımlamalarda finansal okuryazarlık daha çok işletmelerin finansal bilgilerine hâkim olmayı ifade ederken, daha geniş pencereden bakan tanımlamalara göre ise; finansal okuryazarlık, kararların rasyonelliği ve nakdin etkin kullanım ve yönetimine yönelik kararlar alabilme yeteneği olarak ifade edilmiştir (Huston, 2010: 298). Finansal okuryazarlık, kişilerin finansal kaynaklarını etkin şekilde yönetmesine ilişkin bilgi ve yeteneklere sahip olma ve bunları hayatı boyunca finansal güvenliğini sağlamak amacıyla kullanmasıdır (Hastings vd., 2013), bireylerin sahip olduğu finansal bilgileri kullanarak ekonomik kararlarına yönelik algı ve eylemlerini planlamasıdır (Holzmann, 2010), tüketim tercihlerinde etkinliği ve yatırım seçeneklerinde rasyonelliği sağlama çabalarıdır (Courchane vd., 2008: 129), kişilerin finans bilgisi çerçevesinde kararlarını şekillendirme yeteneğidir (Alkaya ve Yağlı, 2015: 586). Finansal okuryazarlık kavramı finansal ürün ve tekniklere ilişkin temel seviyedeki bilgilere sahip olma ve bu bilgileri finansal kararların şekillendirilmesinde kullanma kabiliyeti şeklinde de tanımlanmıştır (Temizel ve Bayram, 2011).

Finansal okuryazarlık kavramına ilişkin oluşturulan tanımlamaların çerçeveleri farklı olmakla beraber genelinde finansal bilgilere olan hâkimiyeti ve bunların kararlarda etkin kullanımını ifade edildiği görülmektedir. Kısacası, finansal okuryazarlıkla ilgili bu çalışma kapsamında bir tanımlama yapmak gerekirse; finansal okuryazarlık, "birey veya işletmelerin ekonomik ve finansal kararlarının etkinliğini 
sağlamak amacıyla sahip olmaları gerekli temel düzeydeki finansal bilgilerin elde edilmesi, değerlendirilmesi ve rasyonel hedeflere yönelik verimli kullanılması” şeklinde ifade edilebilir.

\subsection{Finansal Okuryazarlığın Önemi}

Finansal okuryazarlık, ekonomilerin sağlıklı işleyebilmesi ve alınan kararların etkinliğinin sağlanması açısından önemlidir. Finansal okuryazarlık finansal becerileri geliştirirken, aynı zamanda bireylerin kabiliyetli birer yatırımcı olmasını da sağlamaktadır (Langley, 2008). Bu durum yatırım kararlarının daha rasyonel hale gelmesine, dolayısıyla tasarrufların etkin kullanımına katkı sunmaktadır. Ekonomi biliminde tasarruf önemli konulardan biridir. Sermayenin temelini tasarrufların oluşturduğu ve tasarruf ile yatırımlar arasındaki korelasyon düzeyi göz önüne alındığında, yatırım ve ekonomik büyümenin tasarruf bilinci ve birikimiyle paralellik gösterdiği görülmektedir. Büyüme yatırımlara, yatırımlar ise tasarruflara bağlıdır (Çolak ve Öztürkler, 2012: 4). Ekonomi bilimindeki tasarruf-yatırım-büyüme halkaların oluşumunu ve birleşimini sağlayan ve bu faktörlerin etkinliğini arttıran temel unsurun, finansal okuryazarlık düzeyi olduğu söylenebilir.

Finansal okuryazarlık sadece finansal bilgilere sahip olmayı ifade etmemektedir. Finansal okuryazarlık kişi veya kurumların finansal kararlarını şekillendirmesi için bilgilerin araştırılması, değerlendirilmesi ve hedeflenen amaçlara ulaşılması için etkin kullanılmasına yönelik kabiliyetleri ifade etmektedir (Wagland, 2006). Sahip olunan bilgilerin yarar sağlaması için amaçlar doğrultusunda değerlendirilmesi ve etkili bir şekilde kullanmalarını da gerektirmektedir. Bunun yanında finansal okuryazarlığı önemli hale getiren faktörler aşağıda sıralamıştır (OECD Raporu, 2005):

- Finansal araçların çeşitliliği ve karmaşıklığındaki yükseliş,

- Doğum oranları ve sağlıktaki gelişmelere bağlı olarak ortalama yaşam süresinin artış1,

- Kanunlarla gerçekleştirilen emekliliğe ilişkin düzenlemeler,

- Gelirler ve piyasa koşullarında meydana gelen değişimler,

Yaşam sürecinin belli bir aşamasından sonra bireyler, ekonomik kararlarını kendi başlarına aldıklarından finansal bilgilere sahip olmaları bireylerin kararlarının akılcı olmasını sağlamaktadır. Aynı zamanda toplum kapsamında da ekonomiye ilişkin hedeflerin yakalanabilmesi için finansal okuryazarlık seviyesi önemlidir ve bu seviyenin yükseltilmesi için öğretim kurumlarına büyük görevler düşmektedir. Üniversite hayatı boyunca bireylerin sahip oldukları finans kaynaklarını etkin ve verimli kullanma, tasarruf yapma, yatırım araçlarını değerlendirme gibi hususlarda finansal bilgilerine bağlı olarak alacakları kararların da farklılık göstereceği muhtemeldir. Yapılan birçok çalışmada genel olarak finansal okuryazarlık düzeyinin düşük olduğu ve özellikle ekonomi ve finans bilimlerinin yer almadığı programlarda öğrenim gören öğrencilerin finansal okuryazarlık seviye düşüklüğünün daha fazla olduğu tespit edilmiştir. Makro 
düzeyde ülke ekonomilerinin gelişimi tüm katılımcıların kararlarında etkin ve verimliliği sağlamalarına bağlı olması, ekonomik kararlarda rol oynayan her vatandaşın temel düzeyde finansal okuryazarlığa sahip olmasını gerektirmektedir. Bundan dolayı temel düzeyde finansal okuryazarlığı sağlayacak bilgilerin tüm öğretim programlarında yer almasını sağlayacak düzenlemelere yer verilmesi gereklidir.

Finansal okuryazarlık seviyesinin ölçülmesine ilişkin temel kriter(ler) bulunmamakla birlikte, finansal okuryazarlık düzeyinin belirlenmesi ile ilgili çalışmalarda genellikle; temel kavramlar, faiz hesaplamaları, finansal kurum ve piyasalar gibi göstergelerin kullanıldığı görülmektedir (Moore, 2003). Benzer şekilde finansal okuryazarlığın ölçülmesinde genellikle bireysel bir seviyenin belirlenmeye çalışıldığı görülmektedir. Konuyla ilgili yapılan çalışmaların büyük çoğunluğunda hedef kitle olarak ortaöğretim ve yükseköğretimdeki öğrencilerin finansal okuryazarlık düzeyleri anketlerle ortaya koyulmaktadır (Flores, 2014). Bireysel olarak finansal okuryazarlık seviyenin yükseltilmesi, kişilerin finansal kararlarının rasyonel olmasına ve refah düzeylerinin iyileşmesine önemli katılar sağlayacaktır. Yapılmış çalışmalarda katılımcılar finansal bilgilerini genellikle banka şubeleri, eş-dost tavsiyeleri, internet ortamları, satış personeli gibi informal yollardan edindiklerini ifade etmişlerdir. Rasyonel kararların oluşturulmasında bilginin önemli olması ve elde edilecek bilginin de doğru, güvenilir, güncel gibi özelliklere sahip olması gerekmektedir. Bilgi sağlayıcıların öğretim kurumları gibi formal ortamlardan oluşması bilginin belirtilen özellikleri taşıması açısından önem arz etmektedir.

\section{Literatür Taraması}

Finansal okuryazarlık kavramı derin bir tarihsel geçmişe sahip olmamakla birlikte birçok araştırmacı tarafından farklı boyut ve bakış açısıyla değerlendirilmiştir. Yapılan çalışmalarda üniversite öğrencilerine yönelik finansal okuryazarlık düzeyinin belirlenmesi yoğun şekilde incelenmiştir. Bunun yanında yatırımcılar, aile bireyleri gibi unsurların finansal okuryazarlık düzeylerinin belirlenmesine yönelik çalışmaların da olduğu görülmektedir. Bu çalışmada, finansal okuryazarlığa ilişkin yapılan yayınlara ilişkin literatür taraması kronolojik olarak verilmiştir.

Chen ve Volpe (1998) çalışmalarında farklı üniversitelerde öğrenim gören öğrencilerin finansal okuryazarlık düzeylerini anket yöntemiyle belirlemişler. Elde edilen bulgulara göre finansal okuryazarlık düzeyinin düşük olduğu kesimlerin genellikle; kadınlar, öğrenim sürecinin başında yer alan öğrenciler, gençler, mesleki tecrübesi az kişiler olduğunu belirtmişlerdir.

Lusardi ve Mitchell (2007) çalışmalarında finansal okuryazarlık konusunda belirleyici faktörleri ortaya koymuşlardır. Çalışma sonucunda bireylerin emekliliğe ilişkin beklentilerinin finansal okuryazarlık düzeyinin belirlenmesinde önemli etken olduğu, öğrenimlerinde ekonomi veya finans alanına ilişkin dersleri alan öğrencilerin 
almayanlara göre daha yüksek düzeyde bir finansal okuryazarlığa sahip oldukları belirlenmiştir.

Nano (2013) çalışmasında Arnavutluk’ta üniversite eğitimi alan öğrencilerin finansal okuryazarlık düzeylerinin farklılaşmasında öğrenim gördükleri bölümün etkisini belirlemeye çalışmıştır. Kapsamlı bir katılımcı grubuna yapılan anket çalışmasından elde edilen bulgulara göre, işletme alanında öğrenim görenlerin farklı alanlarda öğrenim görenlere kıyasla finansal okuryazarlık düzeylerinin daha yüksek olduğu, bunun yanında finansal bilgilerin uygulamasına ilişkin alanlar arasında bir farklılığın olmadığını tespit etmiştir.

Er vd. (2014) çalışmalarında üniversitelerin farklı alanlarında öğrenim gören öğrencilere anket yöntem kullanılarak ilgili grupların finansal okuryazarlık seviyelerini belirlemeye çalışmışlardır. Çalışmada elde ettikleri bulgulara göre alanlar arasında istatistiksel anlamda bir farklılığın olduğunu tespit etmişlerdir. Buna göre, öğrenim alanlarına göre öğrencilerin mühendislik ve iktisadi ve idari bilimlerde öğrenim görmelerine bağlı olarak finansal araçları tanıma düzeylerinin farklılaştığı belirlenmiştir. Bunun nedeni olarak da öğrencilerin aldıkları konuyla ilgili derslerin niceliksel ve niteliksel kapsamlarının etkili olduğu ortaya çıkmıştır.

Üniversitelerde öğrenim gören öğrencilerin finansal okuryazarlık seviyelerinin belirlenmesi amacıyla gerçekleştirilen başka bir çalışmada Bozüyük Meslek Yüksekokulu'ndaki sosyal bilim alanlarında öğrenim gören öğrenciler değerlendirilmiştir. Çalışmanın bulgularına göre, finansal okuryazarlık düzeyinin yüksekten düşüğe doğru sıralaması; muhasebe ve vergi uygulamaları, banka ve sigortacılık, diş ticaret ve pazarlama programları şeklinde olduğunu vurgulamıştır (Şahin, 2014).

Kılıç vd. (2015) çalışmalarında Gaziantep Üniversitesi lisans öğrencileri evreninde anket yöntemi kullanarak kapsamdaki öğrencilerin finansal okuryazarlık düzeylerini farklı özellikler çerçevesinde belirlemeye çalışmışlar. Bulgulara göre genel olarak katılımcıların finansal okuryazarlıklarının düşük seviyede olduğu bununla birlikte erkek katılımcıların kadın katılımcılara göre finansal okuryazarlık seviyelerinin daha yüksek düzeyde belirlendiğini ifade etmişlerdir.

Coşkun (2016) çalışmasında finansal okuryazarlığa ilişkin farklı bir boyutu ele almış ve Celal Bayar Üniversitesi'nde öğrenim gören önlisans öğrencilerinin finansal davranış ve tutumlarındaki etkileri bakımından finansal okuryazarlık algılarını tespit etmeye çalışmıştır. Anket yönteminin uygulandığı çalışmada ulaşılan neticelere göre öğrencilerin finansal ürün bilgilerinde genellikle kredi kartı ve vadesiz mevduat hesaplarının yer aldığını, genel anlamda finansal okuryazarlık seviyesinin düşük olduğunu belirlemiştir. 
Demirkol ve Erduru (2017) çalışmalarında Harran Üniversitesi İİBF'deki dördüncü sınıf öğrencilerinin finansal okuryazarlık seviyelerini ve bu seviyenin temelini oluşturan muhasebe-finans derslerine ilişkin algılarını demografik özellikler kapsamında incelemişler. Toplam 447 öğrencinin katılım sağladığı anket yöntemiyle elde edilen veriler; Frekans Analizi, Bağımsız Örneklem T Testi ve Tek Yönlü Varyans Analizi gibi istatistiki tekniklerle analiz edilmiştir. Elde ettikleri bulgulara göre öğrencilerin yeterli düzeyde finansal okuryazarlığa sahip olmadıklarını belirtmişlerdir.

Adıyaman Üniversitesi Turizm Fakültesi öğrencilerine finansal yönetim dersinin finansal kazanıma etkisini ortaya koymak amacıyla bir anket uygulanmıştır. Anket verilerinin analizi SPSS programı ile yapılmıştır. Araştırma sonucunda, öğrencilerin öğrenim kazanımları açısından kendilerini yeterli gördükleri, finansal karar almada daha akılcı ve bilinçli olacakları yönünde bulgular ortaya koyulmuştur. Çalışmada; finansal yönetim dersi algı düzeyinin belirlenen kategorilerde, kadın öğrencilere göre erkek öğrencilerde daha yüksek düzeyde olduğu tespit edilmiştir. Derse yönelik zaman ve öğrenme ile ilgili algı düzeyinin ise Seyahat İşletmeciliği öğrencilerine göre Yiyecek İçecek İşletmeciliği öğrencilerinde daha yüksek düzeyde olduğu ortaya çıkmıştır (Ukav, 2018).

Öcal ve Özcan (2018) Samsun Meslek Yüksekokulu, Muhasebe ve Vergi Bölümü'nde öğrenim gören 80 öğrenciye yönelik finansal okuryazarlık düzeylerini belirlenmek amacıyla anket yöntemi kullanılarak gerçekleştirdikleri çalışmalarında, ilgili bölüm öğrencilerinin cinsiyet ve yaşları ile finansal okuryazarlık seviyeleri arasında istatistiki anlamlılıkta bir fark tespit edilmediğini belirtmişlerdir.

Kocabıyık ve Teker (2018) farklı fakültelerde öğrenim gören öğrencilerin finansal okuryazarlık düzeylerine ilişkin anket çalışması yapmışlardır. Verilerin analizi sonucunda, cinsiyet açısından erkek öğrencilerin kız öğrencilere göre ve İİBF'de öğrenim gören öğrencilerin ise diğer fakülte öğrencilerine kıyasla daha yüksek seviyede finansal okuryazarlık düzeyinde olduklarını belirlemişlerdir. Çalışmada finansal okuryazarlık düzeyini üniversite öğrencileri arasında yükseltmek amacıyla tüm fakülte ve alanlara temel finansal bilgilerin sağlanacağı derslerin okutulması ve bu derslerin başarı kaygısından uzak bir yöntemle öğretilmesinin gerekliliği üzerinde durulmuştur.

Ankara, Hacettepe ve Hacı Bayram Veli Üniversitelerinin İşletme bölümlerinde öğrenim gören son sınıf öğrencilerinin finansal okuryazarlık düzeyinin belirlenmesine yönelik yapılan çalışmada oluşturulan değişkenler kapsamında, öğrencilerin demografik özelliklerine bağlı olarak değişik sonuçlar ortaya çıktığ belirtilmiştir. Elde edilen bulgulara göre katılımcıların finansal okuryazarlık düzeylerinin faiz hesaplama konusunda yüksek; ancak getiri konusunda düşük seviyede olduğu tespit edilmiştir. Katılımcıların finansal okuryazarlık düzeylerinin başarı ve gelir düzeylerinden önemli derecede etkilendiği; ancak cinsiyet, ebeveynlerin eğitim düzeyi gibi faktörlerden ise belirgin bir etkilenmenin olmadığı vurgulanmıştır (Yenilmez, 2019). 
Gümüş ve Pailer (2019) yaptıkları çalışmada, finansal okuryazarlığa ilişkin bilgi, algılama ve uygulamalarına yönelik finans konusunda belli bir eğitime sahip kişiler ile bu eğitimi almamış kişiler arasında bir farklılık olup olmadığını belirlemişlerdir. Çalışmanın katılımcılarını Adnan Menderes Üniversitesi Nazilli İIBF işletme bölümünde öğrenim gören finans eğitimindeki ilgili derslerde başarı sağlamış ve bu dersleri henüz almamış öğrencilerin oluşturduğu ifade edilmiştir. Elde edilen bulgulara göre finans eğitimine yönelik derslerde başarı sağlayan öğrencilerin bu dersleri almamış öğrencilere göre finansal okuryazarlık düzeylerinde farklılığın olduğu, bununla beraber cinsiyet ve çalışma durumu unsurlarına göre ise istatistiksel açıdan anlamlı bir farklılığın olmadığı tespit edilmiştir.

Bozkurt vd. (2019) çalışmalarında tasarruf ve finansal okuryazarlık konularını ele almışlar ve katılımcıların büyük çoğunluğu tasarruflarını bankalarda tuttukları ancak bu tasarrufların yatırım araçlarına dönüştürülmesinde beklenen düzeyin yakalanmadığını tespit etmişlerdir. Konuya ilişkin bilgilendirmelerin veya eğitimlerin bireylerin eğitim hayatlarının başından itibaren verilmeye başlanmasının önemli olduğu, aile bireylerine ve özellikle kadınlara yönelik tasarruf ve finansal okuryazarlığın düzeyini arttırıcı kapsam ve çeşitliliği derin olan eğitim faaliyetlerinin yürütülmesinin gerekliliğini vurgulamışlardır.

Finansal bilgi düzeyini belirlemek amacıyla yapılan çalışmada; veriler anket yöntemi uygulanarak Harran Üniversitesi Suruç Meslek Yüksekokulu'ndaki farklı bölümlerinde öğrenim gören öğrencilerden elde edilmiştir. Öğrencilerin finansal okuryazarlık düzeyleri, frekans yüzde dağılımlarıyla belirlenmeye çalışılmıştır. Bulgular Bankacılık, Sigortacılık ve Finans bölümünde öğrenim gören öğrencilerin sahip oldukları finansal bilgi düzeyinin kapsamdaki diğer bölümlere göre daha iyi durumda olduğu ve katılımcıların genelinde finansal okuryazarlık seviyenin yeterli bir düzeyde olduğu ifade edilmiştir (Şenbayram, 2019).

Tarihsel süreç içerisinde çalışma konusuna ilişkin yukarıda sunulan literatür çalışmaların genelinde finansal okuryazarlığın üniversite öğrencileri, İİBF veya diğer fakülte ve bölümlerin karşılaştırılması şeklinde anketlere dayalı verilerle yürütüldüğü gözlemlenmiştir. Ayrıca günümüze yaklaştıkça akademik çalışmalarda finansal okuryazarlık düzeyinin yanında finansal davranış konularının da belirlenmeye çalışıldı ğ görülmektedir. Bunun yanında bazı çalışmalarda finansal okuryazarlığa etki edebilecek muhtemel faktörlere ilişkin bilgilerin de araştırıldı̆̆ düzeyleri üzerinde etkili olduğu ortaya konulmuştur.

Günümüzde ekonomide baş döndürücü gelişmeler yaşanmaktadır. Bu gelişmeleri anlayabilmek ve buna uygun davranış yöntemleri oluşturmak son derece önemli hale gelmiştir. Bunun bir yansıması olarak da finansal piyasalar oldukça kapsamlı boyutlara ulaşmıştır. Finansal yapı içerisinde yaşanan bu değişikliler ve gelişmeler sistemi karmaşık hale getirebilmektedir. Bu karmaşa, sistem içerisinde yer alan bireylerin karar alma süreçlerini olumsuz yönde etkiyebilmektedir. Alınacak finansal kararlar bireylerin 
ekonomik yaşamları için de son derece önemli olacaktır. Finansal karar alma konumunda olanların bu süreçte yeterli ve uygun bir finansal bilgi düzeyine sahip olmaları önem taşımaktadır.

Dolayısıyla burada finansal bilgi birikimi ön plana çıkmaktadır. Kişilerin finansal bilgi düzeyleri finansal okuryazarlık seviyelerini belirlemede oldukça önemli bir faktördür (Tüfekçi vd., 2017: 58-72). Bununla birlikte finansal piyasaların işleyişi ile ilgili temel düzeyde bilgi sahibi olmanın yanında bu bilgilerin tutum ve davranışlara yansıtılması gerekmektedir. Finansal okuryazarlık ile kişinin; bilgi, beceri, tutum ve davranışları ile parasını iyi yönetebilme, finansal sistem ve araçlarının işleyişi hakkında bilgi sahibi olma, finansal planlar yapabilme, etkili bir iletişim kurabilme gibi özelliklere sahip olması beklenebilir (Gökmen, 2012: 205).

Finans ve türevleri, bireylerin tutum ve davranışlarıyla şekillenmesinden dolayı bir sosyal bilim olmasının yanı sıra derin analizlerin gerekliliği nedeniyle genelde yalnızca uzmanların bir uğraşı alanı olarak algılanmaktadır. Aslında, finansal konular tüm kesimlerin ilgi alanına girmektedir. Ancak finansal sistemin en büyük paydaşları olan tüketici grubu, sistemin karmaşık yapısından dolayı uzmanların kuklaları haline gelmiştir. Finans sisteminde bu denli önemli bir yere sahip olan tüketici grubu, bu sistemin dışında kalarak uzmanlara teslim olmuştur. Bireyler yaşamlarının her anında farklı boyutlarda finansal kararlar almakta ve bu kararlar ilgili bireylerin yaşam şekillerini önemli ölçüde etkilemektedir (Biçer ve Altan, 2016: 1510).

Finansal okuryazarlıkla ilgili olarak yapılan çalışmalarda bireylerin karmaşık yapıları nedeniyle günümüz finansal ürün ve araçlarını kavrama ve değerlendirmede güçlük çektikleri anlaşılmaktadır. Yeterli bilgi birikimine sahip olmadan bilinçsizce alınan kararlar, tarafları ve finansal sistemi olumsuz bir şekilde etkileyebilmektedir. $\mathrm{Bu}$ olumsuzlukları engellemek ve bireylerin finansal gelişmelerden etkin bir şekilde faydalanmalarını sağlamak için finansal okuryazarlık düzeyinin artırılması önemlidir. (Elmas ve Y1lmaz, 2016: 138). Dolayısıyla, Finansal okuryazarlık seviyesini yükseltmenin en temel koşullarından birisi bireylerin finans konularında alacakları eğitimin nicelik ve nitelik olarak geliştirilmesidir.

Türkiye'de lisans düzeyinde finansal okuryazarlığın belirlenmesine yönelik oldukça fazla sayıda çalışma yapılmıştır. Ancak doğrudan Meslek yüksekokullarında öğrenim gören öğrencilere yönelik çalışma sayısı lisans öğrencilerine yönelik yapılan çalışmalar kadar değildir. Bu nedenle meslek yüksekokullarının bir örneği olarak Adıyaman Üniversitesi Kâhta Meslek Yüksekokulu öğrencilerinin finansal okuryazarlık nitelikleri incelenmiştir. Bu çalışmada, Finans, Bankacılık ve Sigortacılık Bölümü ile Muhasebe ve Vergi Bölümü öğrencilerinin finansal okuryazarlık bilgi düzeyleri ve bu bilgi düzeylerinin çeşitli faktörlere göre farklılık gösterip göstermediğinin belirlenmesi amaçlanmıştır. Bu amaçla öncelikle finansal okuryazarlık ile ilgili kavramsal çerçeve ortaya konulmuş, konu ile ilgili literatür çalışmaları özetlenmiş ve öğrencilerin finansal 
okuryazarlık bilgi düzeylerinin belirlenmesine yönelik uygulama ve bulgularına yer verilmiştir.

\section{Materyal ve Yöntem}

Bu çalışma, Adıyaman Üniversitesi Kâhta Meslek Yüksekokulu'nda iki farklı bölümde (Finans, Bankacılık ve Sigortacılık ile Muhasebe ve Vergi) Finansal Yönetim dersi alan ikinci sınıf öğrencilerinin derse yönelik algılarını ve finansal okuryazarlık düzeylerini tespit etmek amacıyla yapılmıştır. Çalışmada veriler anket tekniği kullanılarak elde edilmiştir. 88 öğrenciye uygulanan ankette Geiger ve Ogilby (2000: 72) tarafından geliştirilen ölçek kullanılmıştır. Katılımcıların derse karşı algı düzeylerine ilişkin veriler anket yöntemi kullanılarak belirli kategoriler (başarı, kariyer, ödül, zaman, merak, motivasyon, öğrenme, eğitmen ve sıkıcı) çerçevesinde elde edilmiştir. Katılımcıların derse ilişkin algılarını ölçmeye yönelik sorularda 5'li Likert ölçeği (1; Kesinlikle Katılmıyorum, 2; Katılmıyorum, 3; Kısmen Katılıyorum, 4; Katılıyorum, 5; Kesinlikle Katılıyorum) kullanılmıştır. Anketle elde edilen verilerin normal dağılım gösterdiği tespit edilmiş ve parametrik testlerin uygulanmasında herhangi bir sakınca bulunmadığ 1 görülmüştür. Bu kapsamda veriler SPSS programı kullanılarak betimsel istatistik, bağımsız gruplar arası t-testi ve ANOVA testi ile analiz edilerek çözümlenmiştir.

\section{Analiz ve Sonuçları}

\subsection{Katılımcıların Demografik Özellikleri}

Anket uygulanan 88 katılımcıya ait demografik verilere ilişkin frekans ve yüzde dağılımları Tablo 1'de sunulmuştur. Katılımcıların \%35,2'si muhasebe ve vergi bölümünde, $\% 64,8$ 'i ise finans, bankacılık ve sigortacılık bölümünde eğitim görmektedir. Anket uygulanan öğrencilerin \%33,0'ü kadın, \%67,0'si erkektir. Öğrencilerin yaşları incelendiğinde \%21,6'sının 20,\%39,8'inin 21 ve \%38,6'sının 22 ve üstü yaş grubunda olduğu görülmektedir. Katılımcıların genel not ortalamaları itibariyle dağılımlarına bakıldığında \% 15,9'unun 0-1.99, \% 71,6'sının 2.00-2,99 arasında olduğu, $\% 12,5$ 'inin ise 3.00 ve üzeri olduğu izlenmektedir.

Tablo 1: Betimsel İstatistiki Bilgiler

\begin{tabular}{|l|l|l|l|l|l|}
\hline Bölüm & Frekans & Yüzde $(\boldsymbol{\%})$ & Cinsiyet & Frekans & Yüzde (\%) \\
\hline MVU* & 31 & 35.20 & Kadın & 29 & 33.00 \\
\hline FBS* & 57 & 64.80 & Erkek & 59 & 67.00 \\
\hline Toplam & 88 & 100.00 & Toplam & 88 & 100.00 \\
\hline Yaș & Frekans & Yüzde (\%) & G. Not Ort. & Frekans & Yüzde (\%) \\
\hline 20 & 19 & 21.60 & $0-1.99$ & 14 & 15.90 \\
\hline 21 & 35 & 39.80 & $2.00-2.99$ & 63 & 71.60 \\
\hline $22+$ & 34 & 38.60 & $3.00+$ & 11 & 12.50 \\
\hline Toplam & 88 & 100.00 & Toplam & 88 & 100.00 \\
\hline
\end{tabular}

MVU* : Muhasebe ve Vergi Uygulamaları Bölümü

FBS* : Finans, Bankacılık ve Sigortacılık Bölümü 


\subsection{Değişkenlere Ait İstatistikler}

Tablo 2 katılımcıların Finansal Yönetim dersine ilişkin algı düzeyini belirten sorulara ilişkin ortalama ve standart sapma değerlerini göstermektedir. Yapılan istatistiksel analiz neticesinde algı puanı ortalamalarının 4 ve 4'e yakın değerler olduğu görülmektedir. Bu durum öğrencilerin Finansal Yönetim dersi ile ilgili algı düzeylerinin oldukça yüksek olduğunu göstermektedir. Analiz neticesinde, (4.40) ortalama değerle, "Derste Eğitmenin Etkili Olduğunu Düşünüyorum" seçeneğinin en yüksek değerde olduğu belirlenmiştir. İkinci sırada 4.08 ortalama puanla "Dersteki Başarım Benim İçin Ödüllendiricidir" ifadesi gelmektedir. En düşük algı puanı ise (3.56) ortalama ile "Derste Başarılı Olmak İçin Motive Oldum” ifadesidir. Dolayısıyla, Finansal Yönetim derisine ait algı düzeyinin oldukça yüksek olduğu görülmektedir.

Tablo 2: Ölçek Cevaplarının Ortalaması

\begin{tabular}{|l|l|l|l|}
\hline İfadeler & N & Ortalama & S. Sapma \\
\hline İş Yaşamımda Başarılı Olmamı Sağlayacaktır & 88 & 4,13 & 0,828 \\
\hline Kariyerimde Başarılı Olmamı Sağlayacaktır & 88 & 4,07 & 0,894 \\
\hline Dersteki Başarım Benim İçin Ödüllendiricidir & 88 & 4,08 & 0,874 \\
\hline Diğer Derslere Göre Daha Çok Çalışmalıyım & 88 & 3,92 & 0,847 \\
\hline Dersin İlerleyen Sürecini Merak Ediyorum & 88 & 3,68 & 1,001 \\
\hline Derste Başarılı Olmak İçin Motive Oldum & 88 & 3,56 & 0,920 \\
\hline Dersten Çok Şey Öğrendiğimi Biliyorum & 88 & 3,75 & 0,938 \\
\hline Derste Eğitmenin Etkili Olduğunu Düşünüyorum & 88 & 4,40 & 0,865 \\
\hline Dersin Sıkıcı Olduğunu Düşünüyorum & 88 & 3,77 & 1,122 \\
\hline
\end{tabular}

\subsection{Bağımsız Gruplar İçin t-Testi Sonuçları}

Bağımsız gruplar arası t-testi iki grup arasında karşılaştırma yapmaya imkân tanıyan bir analizdir (Altunışık vd, 2007:175).

\subsubsection{Ders Algı Puanlarının Cinsiyete Göre Farklılığı}

$\mathrm{H}_{0}$ : Katılımcıların Finansal Yönetim dersi algı düzeyleri cinsiyete göre anlamlı bir farklılık göstermez.

$\mathrm{H}_{1}$ : Katılımcıların Finansal Yönetim dersi algı düzeyleri cinsiyete göre anlamlı bir farklılık gösterir. 
Tablo 3'te görülebileceği üzere alg1 ölçeğinin “zaman” kategorisi bağımsız gruplar arası $\mathrm{t}$ testi sonucunda, finansal yönetim dersi alg1 düzeyinin ortalamaları arasındaki fark anlamlı bulunmuştur $(\mathrm{t}=2,099 ; \mathrm{p}<.05)$.

\section{Tablo 3: Ders Algı Puanlarının Cinsiyete Göre Farklılığını İnceleyen Bağımsız Gruplar Arası t-Testi}

\begin{tabular}{|c|c|c|c|c|c|c|}
\hline İfadeler & Cinsiye & $\mathbf{N}$ & Ort. & SS & $\mathbf{t}$ & (p) \\
\hline \multirow{2}{*}{$\begin{array}{l}\text { İş } \quad \text { Hayatımda } \quad \text { Başarılı } \\
\text { Sağlayacaktır (BAŞARI) }\end{array}$} & Erkek & 59 & 4,14 & 0,840 & \multirow{2}{*}{0,170} & \multirow{2}{*}{0,865} \\
\hline & Kadın & 29 & 4,10 & 0,817 & & \\
\hline \multirow{2}{*}{$\begin{array}{l}\text { Kariyerimde Başarılı Olmamı Sağlayacaktır } \\
\text { (KARIYER) }\end{array}$} & Erkek & 59 & 4,05 & 0,972 & \multirow{2}{*}{$-0,258$} & \multirow{2}{*}{0,797} \\
\hline & Kadın & 29 & 4,10 & 0,724 & & \\
\hline \multirow{2}{*}{$\begin{array}{llll}\text { Dersteki } & \text { Başarım } & \text { Benim } & \text { İçin } \\
\text { Ödüllendiricidir (ÖDÜL) } & & \end{array}$} & Erkek & 59 & 4,10 & 0,923 & \multirow{2}{*}{0,337} & \multirow{2}{*}{0,737} \\
\hline & Kadın & 29 & 4,03 & 0,778 & & \\
\hline \multirow{2}{*}{$\begin{array}{l}\text { Diğer Derslere Göre } \\
\text { Çalışmalıyım (ZAMAN) }\end{array}$} & Erkek & 59 & 4,05 & 0,818 & \multirow{2}{*}{2,099} & \multirow{2}{*}{0,039} \\
\hline & Kadın & 29 & 3,66 & 0,857 & & \\
\hline \multirow{2}{*}{$\begin{array}{l}\text { Dersin İlerleyen Sürecini Merak Ediyorum } \\
\text { (MERAK) }\end{array}$} & Erkek & 59 & 3,71 & 1,068 & \multirow{2}{*}{0,400} & \multirow{2}{*}{0,690} \\
\hline & Kadın & 29 & 3,62 & 0,862 & & \\
\hline \multirow{2}{*}{$\begin{array}{l}\text { Derste Başarılı Olmak İçin Motive Oldum } \\
\text { (MOTIVASYON) }\end{array}$} & Erkek & 59 & 3,51 & 0,935 & \multirow{2}{*}{$-0,701$} & \multirow{2}{*}{0,485} \\
\hline & Kadın & 29 & 3,66 & 0,897 & & \\
\hline \multirow{2}{*}{$\begin{array}{l}\text { Dersten Çok Şey Öğrendiğimi Biliyorum } \\
\text { (ÖĞRENME) }\end{array}$} & Erkek & 59 & 3,71 & 0,983 & \multirow{2}{*}{$-0,542$} & \multirow{2}{*}{0.589} \\
\hline & Kadın & 29 & 3,83 & 0,848 & & \\
\hline \multirow{2}{*}{$\begin{array}{l}\text { Derste } \quad \text { Eğitmenin } \quad \text { Etkili } \\
\text { Düşünüyorum (EĞITMEN) }\end{array}$} & Erkek & 59 & 4,42 & 0,875 & \multirow{2}{*}{0,400} & \multirow{2}{*}{0,690} \\
\hline & Kadın & 29 & 4,34 & 0,857 & & \\
\hline \multirow{2}{*}{$\begin{array}{l}\text { Dersin S1kıcı Olduğunu } \\
\text { (SIKICI) }\end{array}$} & Erkek & 59 & 3,76 & 1,179 & \multirow{2}{*}{$-0,119$} & \multirow{2}{*}{0,906} \\
\hline & Kadın & 29 & 3,79 & 1,013 & & \\
\hline
\end{tabular}

\subsubsection{Katılımcıların Ders Algılarının Bölümlere Göre Farklılığı}

Araştırmada incelenen diğer bir konu, öğrencilerin finansal yönetim derisi alg1 düzeylerinin okudukları bölümlere göre farklılık gösterip göstermediğidir. Konuya ilişkin hipotezler şu şekilde belirlenmiştir:

$\mathrm{H}_{0}$ : Katılımcıların Finansal Yönetim dersi algı düzeyleri bölüme göre anlamlı bir farklılık göstermez.

$\mathrm{H}_{1}$ : Katılımcıların Finansal Yönetim dersi algı düzeyleri bölüme göre anlamlı bir farklılık gösterir.

Araştırmaya katılan bireylerin "Başarı" ile ilgili algı düzeyleri ( $\mathrm{t}=2,167 ; \mathrm{p}<.05)$ bölüme göre anlamlı farklılık göstermektedir. Ayrıca öğrencilerin "Öğrenme” ile ilgili 
alg1 düzeylerinde bölümler arası anlamlı bir farkın olduğu anlaşılmaktadır $(\mathrm{t}=2,779$; $\mathrm{p}<.05)$.

\section{Tablo 4: Ders Algı Puanlarının Bölümlere Göre Farklılığını İnceleyen Bağımsız Gruplar Arası t-Testi}

\begin{tabular}{|c|c|c|c|c|c|c|}
\hline İfadeler & Böl. & $\mathbf{N}$ & Ort. & SS & $\mathbf{t}$ & (p) \\
\hline \multirow{2}{*}{ 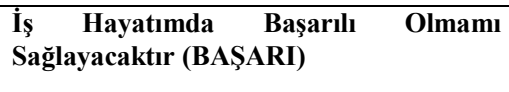 } & MVU & 31 & 3,87 & 0,885 & \multirow[t]{2}{*}{$-2,167$} & \multirow[t]{2}{*}{$\mathbf{0 , 0 3 3}$} \\
\hline & FBS & 57 & 4,26 & 0,768 & & \\
\hline \multirow{2}{*}{$\begin{array}{l}\text { Kariyerimde Başarılı Olmamı Sağlayacaktır } \\
\text { (KARIYER) }\end{array}$} & MVU & 31 & 3,94 & 1,063 & \multirow[t]{2}{*}{$-1,027$} & \multirow[t]{2}{*}{0,307} \\
\hline & FBS & 57 & 4,14 & 0,789 & & \\
\hline \multirow{2}{*}{$\begin{array}{lcc}\text { Dersteki } \quad \text { Başarım } & \text { Benim } & \text { İçin } \\
\text { Ödüllendiricidir (ÖDÜL) } & & \end{array}$} & MVU & 31 & 3,90 & 1,044 & \multirow[t]{2}{*}{$-1,404$} & \multirow[t]{2}{*}{0,164} \\
\hline & FBS & 57 & 4,18 & 0,759 & & \\
\hline \multirow{2}{*}{ 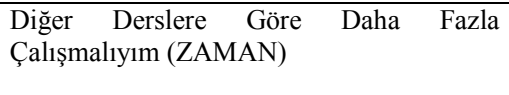 } & MVU & 31 & 3,97 & 1,016 & \multirow[t]{2}{*}{0,384} & \multirow[t]{2}{*}{0,702} \\
\hline & FBS & 57 & 3,89 & 0,748 & & \\
\hline \multirow{2}{*}{$\begin{array}{l}\text { Dersin İlerleyen Sürecini Merak Ediyorum } \\
\text { (MERAK) }\end{array}$} & MVU & 31 & 3,52 & 1,092 & \multirow[t]{2}{*}{$-1,148$} & \multirow[t]{2}{*}{0,254} \\
\hline & FBS & 57 & 3,77 & 0,945 & & \\
\hline \multirow{2}{*}{$\begin{array}{l}\text { Derste Başarılı Olmak İçin Motive Oldum } \\
\text { (MOTIVASYON) }\end{array}$} & MVU & 31 & 3,48 & 0,962 & \multirow[t]{2}{*}{$-0,546$} & \multirow[t]{2}{*}{0,586} \\
\hline & FBS & 57 & 3,60 & 0,904 & & \\
\hline \multirow{2}{*}{$\begin{array}{l}\text { Dersten Çok Şey Öğrendiğimi Biliyorum } \\
\text { (ÖĞRENME) }\end{array}$} & MVU & 31 & 3,39 & 0,955 & \multirow[t]{2}{*}{$-2,779$} & \multirow[t]{2}{*}{0.007} \\
\hline & FBS & 57 & 3,95 & 0,875 & & \\
\hline \multirow{2}{*}{ 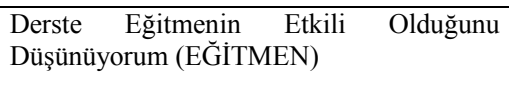 } & MVU & 31 & 4,16 & 1,098 & \multirow[t]{2}{*}{$-1,920$} & \multirow[t]{2}{*}{0,100} \\
\hline & FBS & 57 & 4,53 & 0,684 & & \\
\hline \multirow{2}{*}{$\begin{array}{l}\begin{array}{l}\text { Dersin Sıkıcı Olduğunu } \\
\text { (SIKICI) }\end{array} \\
\text { Düşünüyorum }\end{array}$} & MVU & 31 & 3,65 & 1,082 & \multirow[t]{2}{*}{$-0,785$} & \multirow[t]{2}{*}{0,435} \\
\hline & FBS & 57 & 3,84 & 1,146 & & \\
\hline
\end{tabular}

\subsubsection{Katılımcıların Finansal Okur Yazarlık Düzeylerini Cinsiyete Göre Farklılığını İnceleyen Bağımsız Gruplar Arası t-Testi}

Katılımcıların finansal okuryazarlık düzeylerinin cinsiyete göre farklılığı test edilmiştir. Araştırma hipotezleri şu şekilde oluşturulmuştur.

$\mathrm{H}_{0}$ : Katılımcıların finansal okuryazarlık düzeyleri cinsiyet açısından anlamlı farklılık göstermez.

$\mathrm{H}_{1}$ : Katılımcıların finansal okuryazarlık düzeyleri cinsiyet açısından anlamlı farklılık gösterir.

Finansal okuryazarlık düzeylerini cinsiyet açısından farklılı̆̆ını inceleyen bağımsız gruplar arası $t$ testine göre anlamlı bir fark bulunmamıştır $(t=-1,559 ; \mathrm{p}>.05)$. 
Yani kadın ve erkek öğrencilerin finansal okuryazarlık düzeylerinde anlamlı bir farklılığın olmadığı görülmüştür.

Tablo 5: Katılımcıların Finansal Okuryazarlık Düzeylerini Cinsiyete Göre Farklılığını İnceleyen Bağımsız Gruplar Arası t-Testi

\begin{tabular}{|l|l|l|l|l|l|}
\hline Grup Adı & N & Ort. & SS & t & Anlamlılı (p) \\
\cline { 1 - 4 } Erkek & 59 & 3,3931 & 0,30453 & $-1,559$ & 0,123 \\
\cline { 1 - 3 } & 29 & 3,5157 & 0,42046 & & \\
\hline
\end{tabular}

\subsubsection{Katılımcıların Finansal Okuryazarlık Düzeylerinin Bölüme Göre} Farklılığını İnceleyen t-Testi

Katılımcıların finansal okuryazarlık düzeylerinin bölümlere göre farklılığı incelenmiştir. Buna göre hipotezler aşağıdaki şekilde belirlenmiştir.

$\mathrm{H}_{0}$ : Katılımcıların finansal okuryazarlık düzeyleri okudukları bölüme göre farklılık göstermez.

$\mathrm{H}_{1}$ : Katılımcıların finansal okuryazarlık düzeyi okudukları bölüme göre farklılık gösterir.

Finansal okuryazarlık düzeylerini öğrencilerin okudukları bölümlere göre farklılığını inceleyen bağımsız gruplar arası t testi analiz sonuçlarına göre gruplar arasında bir fark yoktur (t=-0,508; $\mathrm{p}>.05)$. Finansal okuryazarlık düzeyleri bölümlere göre anlamlı farklılık göstermediğinden $\mathrm{H}_{1}$ hipotezi ret edilmiştir.

Tablo 6: Finansal Okuryazarlık Düzeylerini Bölüme Göre Farklılığını İnceleyen Bağımsız Gruplar Arası t-Testi

\begin{tabular}{|l|l|l|l|l|l|}
\hline Grup Adı & N & Ort. & SS & t & Anlamlılık (p) \\
\cline { 1 - 4 } MVU & 31 & 3,4077 &, 29543 & $-0,508$ & 0,613 \\
\cline { 1 - 2 } & 57 & 3,4475 &, 37727 & & \\
\hline
\end{tabular}

4.3.6. Finansal Okuryazarlık Düzeylerinin Katılımcıların Ortalama Notuna Göre Farklılığını İnceleyen Anova Testi

Katılımcıların finansal okuryazarlık düzeyleri ortalama nota göre incelenmiştir. Hipotezler şu şekilde belirlenmiştir: 
H0: Katılımcıların finansal okuryazarlık düzeyleri ortalama nota göre istatistiki anlamlılıkta bir farklılık göstermez.

H1: Katılımcıların finansal okuryazarlık düzeyleri ortalama nota göre istatistiki anlamlılıkta bir farklılık gösterir.

Finansal okuryazarlık düzeyinin not ortalamasına göre farklılığının incelendiği ANOVA sonuçları grup ortalamalarının istatistiksel açıdan anlamlı bir farka $(p=0,001$; $\mathrm{p}<05)$ sahip olduğunu göstermektedir. Dolayısıyla H0 hipotezi ret edilirken, H1 hipotezi kabul edilmiştir.

\section{Tablo 7: Katılımcıların Finansal Okuryazarlık Düzeylerinin Ortalama Notlara Göre Farklılığını İnceleyen Anova Testi}

\begin{tabular}{|l|l|l|l|l|l|}
\hline Grup Adı & N & Ort. & SS & F & Anlamlılık (p)* \\
\hline $0-1.99$ & 14 & 3,2302 & 0,19613 & 7,195 & $\mathbf{0 , 0 0 1}$ \\
\cline { 1 - 4 } & & & 0,33258 & & \\
\cline { 1 - 3 } & 63 & 3,4272 & 0,41533 & & \\
\hline
\end{tabular}

Çalışmada katılımcıların finansal okuryazarlık düzeylerinin cinsiyete, bölümlere ve not ortalamalarına göre ortalama puanlarının 3,2302 ile 3,7284 arasında değiştiği görülmektedir. $\mathrm{Bu}$ durum katılımcıların finansal okuryazarlık düzeyinin ortalamanın üzerinde olduğunu göstermektedir. Oysa yukarıda sunulan literatürde genel olarak benzer çalışmalarda finansal okur yazarlık düzeyinin düşük olduğu belirtilmiştir. Katılımcıların finansal okur yazarlık düzeyinin literatüre göre ortalamanın üzerinde tespit edilmesinin ana sebebi, çalışmanın katılımcıların Finansal Yönetim dersini aldıktan sonra yapılmasından ileri geldiği düşünülmektedir.

\section{Sonuç}

$\mathrm{Bu}$ çalışmada, önlisans seviyesinde finans eğitimi alan bireylerin finansal yönetim dersiyle ilgili algı ve finansal okuryazarlık seviyelerini tespit etmek, elde edilen ortalama puanların öğrencilerin cinsiyet, bölüm ve not ortalamaları değişkenlerine göre farklılık oluşturup oluşturmadığının tespiti amaçlanmıştır. Katılımcıların genel olarak finansal yönetim dersine ilişkin algılarının yüksek olduğu belirlenmiştir. Katılımcıların finansal yönetim derisine ait alg1 düzeylerinin cinsiyete göre bir farkının olup olmadığını belirlemek için gruplar arası bağımsız t testi uygulanmıştır. Analiz neticesinde; erkek katılımcıların "zaman" kategorisinde algı puanlarının kadınlara göre daha yüksek olduğu ortaya çıkmıştır. Finans, Bankacılık ve Sigortacılık bölümü öğrencilerinin "Başarı" ve "Öğrenme" ile ilgili algı düzeyleri, Muhasebe ve Vergi 
bölümüne göre daha yüksek olup "Başarı” ve "Öğrenme” boyutlarında her iki bölüm arasında anlamlı bir farkın olduğu görülmüştür.

Katılımcıların finansal okuryazarlık düzeyleri ile ilgili t testi sonuçlarına göre finansal okuryazarlık seviyesinin cinsiyet ve bölümler açısından istatistiki anlamlılıkta bir farklılık göstermediği tespit edilmiştir. Bu durum dersi alan tüm katılımcıların belirli bir bilgi düzeyini eriştiklerini göstermektedir. Finansal okuryazarlık düzeyi katılımcıların başarı notu ortalamalarına göre ise farklılık göstermektedir. Yani katılımcıların not ortalamaları yükseldikçe finansal okuryazarlık düzeyi de artmaktadır.

Araştırmaya katılımcılarının finansal yönetim dersine karşı olumlu tutuma sahip oldukları anlaşılmaktadır. Katılımcıların finansal okuryazarlık düzeylerinin ortalama puanlarının 3,2302 ile 3,7284 arasında değiştiği görülmektedir. Bu durum katılımcıların finansal okuryazarlık düzeyinin ortalamanın üzerinde olduğunu ve bunun asıl sebebinin de çalışmanın finansal yönetim dersinin verilmesinden sonra yapılmış olmasından ileri gelebileceği değerlendirilmektedir. Finansal okuryazarlık düzeyinin cinsiyet, bölüm ve not ortalamalarına göre ortaya çıkan farklılıkların olağan olduğu düşünülmektedir. Katılımcıların finansal yönetim derisi algı düzeyleri dikkate alındığında, eğitmenin dersin anlaşılmasında önemli bir etkisinin olduğu görülmektedir. Finans eğitiminde çağa uygun eğitim programları ve zengin içerikli müfredatlar ile bu içeriği ögrencilere etkili aktaran eğitmenlerin varlığının finansal okuryazarlık düzeyini önemli ölçüde yükselteceği düşünülmektedir. Dolayısıyla finans sektörünün ihtiyaç duyduğu, çağın gerektirdiği donanıma sahip elemanların yetişmesinde eğitim programları ve eğiticilerin niteliklerinin önemli olduğu söylenebilir.

\section{Kaynakça}

Alkaya, A., ve Yağlı, İ., (2015). Finansal Okuryazarlık - Finansal Bilgi, Davranış Ve Tutum: Nevşehir Hacı Bektaşi Veli Üniversitesi Öğrencileri Üzerine Bir Çalışma. Uluslararası Sosyal Araştırmalar Dergisi, 585-599.

Altunışık, R., Coşkun, R., Bayraktaroğlu, S., Yıldırım, E. (2007). Sosyal Bilimlerde Araştırma Yöntemleri SPSS Uygulamalı. Sakarya: Sakarya Yayıncılık.

Biçer, E.B., Altan, F. (2016). Üniversite Öğrencilerinin Finansal Okuryazarlık ile İlgili Tutum ve Davranışlarının Değerlendirilmesi. Atatürk Üniversitesi Sosyal Bilimler Enstitüsü Dergisi, 20(4), 1501-1517.

Bozkurt, E., Toktaş, Y., ve Altıner, A., (2019). Türkiye'de Tasarruf ve Finansal Okuryazarlık Üzerine Bir Araştırma. Elektronik Sosyal Bilimler Dergisi, 18(72), 1580-1605.

Chen, H., ve Volpe, R. P., (1998). An analysis of personal financial literacy among college students. Financial Services Review, 7, 107-128. 
Coşkun, S. (2016). Üniversite Öğrencilerinin Finansal Davranış ve Tutumlarının Belirlenmesi: Finansal Okuryazarlık Algıları Üzerine Bir Araştırma. Insan ve Toplum Bilimleri Araştırmaları Dergisi, 5(7), 2247-2258.

Courchane, M., Gailey A. ve Zorn, P. (2008). Consumer creditliteracy: What price perception? Journal of Economicsand Business, 60, 125-138.

Çolak, Ö. F. ve Öztürkler, H. (2012). Tasarrufun Belirleyicileri: Küresel Tasarruf Eğiliminde Değişim ve Türkiye'de Hane halkı Tasarruf Eğiliminin Analizi. Bankacılar Dergisi, 82, 3-44.

Demirkol, Ö. F. ve Erduru, İ. (2017). Üniversite Öğrencilerinin Finansal Okuryazarlık Düzeylerinin Tespitine Yönelik Bir Araştırma: Harran Üniversitesi Örneği, İsletme ve İktisat Çalışmaları Dergisi, 5(4), 12-26.

Elmas, B. ve Yılmaz, H. (2016). Finansal Okuryazarlık: Ağrı İbrahim Çeçen Üniversitesi İktisadi ve İdari Bilimler Fakültesi Öğrencileri Üzerine Bir Çalışma. Ă̆rı İbrahim Çeçen Üniversitesi, Sosyal Bilimler Enstitüsü Dergisi, 2(1), 115140.

Er, F., Temizel, F., Özdemir, A. ve Sönmez, H. (2014). Lisans Eğitim Programlarının Finansal Okuryazarlık Düzeyine Etkisinin Araştırılması: Türkiye Örneği, Anadolu Üniversitesi Sosyal Bilimler Dergisi, 14(4), 113-125.

Eskici, Y. (2014). Seçilmiş Ülke Örnekleriyle Finansal Okuryazarlı̆̆ın Önemi ve Tasarruflar Üzerindeki Etkileri, Adnan Menderes Üniversitesi, Sosyal Bilimler Enstitüsü, İşletme Ana Bilim Dalı Yüksek Lisans Tezi, Aydın.

Flores, C., (2014). First generation college student financial literacy: Impact of selfefficacy and behavior. Unpublished $\mathrm{PhD}$ Dissertation,Washingon State University Department of Education.

Fox, J., Bartholomae, S. ve Lee, J. (2005). Building the case for financial education. The Journal of ConsumerAffairs, 39 (1), 195-214.

Geiger, M. A. ve Ogilby, S.M. (2000). The first course in accounting: students' perceptions and their effect on the decision to major in accounting. Journal of Accounting Education, 18(1), 63-78.

Gümüş, U.T. ve Pailer, M.K. (2019). Öğrencilerin Finans Dersi Alma Durumunun Finansal Okur Yazarlık Seviyesine Etkisi: Bir Nazilli Örneği. Uluslararası Toplum Araştırmaları Dergisi, 11(18), 1495-1516.

Gökmen, H. (2012). Finansal Okuryazarlık. İstanbul: Hiperlink Yayınları. 
Hastings, J. S., Madrian, B. C. ve William L. S. (2013). Financial Literacy, Financial Education and Economic Outcomes. Annual Review of Economics, 5(1), 347373.

Holzmann, R. (2010) Bringing financial literacy and education to low and middle in come countries: the need to review, adjust and extend current wisdom, World Bank Social Protection Discussion Paper (No 56501), Washington DC: World Bank Group.

Huston, S. J. (2010). Measuring Financial Literacy. The Journal of Consumer Affairs, 44(2), 296-314.

Kılıç, Y., Ata, H. A. ve Seyrek, İ. H. (2015). Finansal Okuryazarlık: Üniversite Öğrencilerine Yönelik Bir Çalışma. Muhasebe ve Finansman Dergisi, 129-145.

Kocabıyık, T. ve Teker, T., (2018). Finansal Okuryazarlık: Süleyman Demirel Üniversitesi Öğrencileri Üzerine Bir Araştırma. Stratejik ve Sosyal Araştırmalar Dergisi, 2(2), 117-144.

Langley, P. (2008). The everyday life of global finance: Saving and borrowing in AngloAmerica. OUP Oxford.

Lusard1, A. ve Mitchell, O. S., (2007). Financial Literacy and Retirement Planning: New Evidence from the Rand American Life Panel. Michigan Retirement Research Center Research Paper No. 157.

Moore, D. L. (2003). Survey of Financial Literacy in Washington State: Knowledge,Behavior, Attitudes, And Experiences. Washington State Department of Financial Institutions.

Nano, D. (2003). Major Differences In Financial Literacy Among Albanıan Unıversity Students. Regional Science Conference with International Participation, 389-394.

Oecd (2005). Improving Financial Literacy Analysis of Issues and Policies. Organisation for Economic Cooperation and Development.

Öcal, M. ve Özcan, K. (2018). Muhasebe ve Vergi Bölümü Öğrencilerinin Finansal Okuryazarlık Düzeylerinin İncelenmesi: Samsun Meslek Yüksekokulu Örneği. The Journal of Academic Social Science Studies International Journal of Social Science, Number: 72, Autumn III, 137-143.

Özçam M. (2006). Yatırımcı Eğitimi: Dünya Uygulamaları ve Türkiye için Öneriler, Sermaye Piyasası Araştırma Raporu, Ankara. 
Payziner, P. D. (2017). Finansal Okuryazarlığa İlişkin Tutum ve Davranışların Belirlenmesi: Sağlık Yönetimi Bölümü Öğrencileri Üzerine Bir Araştırma. Akademik Sosyal Araştırmalar Dergisi, 5(58), 432-452.

Şahin, C. (2014). Bir Meslek Yüksekokulu Öğrencilerinin Finansal Okuryazarlık Düzeyinin Belirlenmesine İlişkin Bir Araştırma: Bozüyük Meslek Yüksekokulu Örneği. Uluslararası Hakemli Tasarım ve Mimarlık Dergisi, 1(2), 19-29.

Şenbayram, E. A. (2019). Finansal Okuryazarlık: Harran Üniversitesi Suruç Meslek Yüksekokulu Öğrencilerine Yönelik Bir Araştırma. Harran Üniversitesi IIIBF Dergisi, 3(3), 1-21.

Temizel, F. ve Bayram, F., (2011). Finansal Okuryazarlık: Anadolu Üniversitesi İktisadi ve İdari Bilimler Fakültesi (İ̈BF) Öğrencilerine Yönelik Bir Araştırma. C. $\ddot{U}$. İktisadi ve İdari Bilimler Dergisi, 12(1), 73-86.

Tüfekçi, B., Erdoğan, S., Karaca, S.S. ve Seçgin, N. (2017). Finansal Okuryazarlık Bilgi Düzeyinin Ölçülmesi: İşletme Bölümü Öğrencileri Üzerine Bir Uygulama. International Journal of Business, Economics and Management Perspectives, 2(7), 58-72.

Ukav, İ., (2018). Finansal Yönetim Eğitimi Alan Öğrencilerin Öğrenim Kazanımları Üzerine Bir Araştırma, II. Uluslararası Multidisipliner Çalışmaları Kongresi, 4-5 Mayıs 2018, Adana, Proceeding Book, ISBN: 978-605-258-102-5 (3.c). 61-75.

Wagland, S. (2006). Financial Literacy in the Context of Literacy in General. Fifth Australian Society of Heterodox Economists Conference.

Yardımcıoğlu, M., ve Yörük, A., (2016). Türkiye'deki Finansal Okuryazarlığın ve Finansal Farkındalığın Durumu. Muhasebe ve Vergi Uygulamaları Dergisi, Temmuz (2), 173-208.

Yenilmez, B. (2019). İşletme Bölümü Son Sınıf Öğrencilerin Finansal Okuryazarlık Düzeyi (Ankara-Hacı Bayram Veli-Hacettepe Üniversitesi Örneği). Fırat Üniversitesi İ̈BF Uluslararası İktisadi ve İdari Bilimler Dergisi, 3(2), 277-308. 